Situs Jurnal : http://ejurnal.stiepancasetia.ac.id/index.php/jieb

Jilid 4 Nomor 3 November 2018

Hal $319-329$

\title{
PENGARUH KUALITAS PELAYANAN TERHADAP KEPUASAAN PELANGGAN PADA KARAOKE INUL VIZTA TANJUNG
}

\section{Imansyah* dan Haris Irawan}

Abstract: The purposes of this research is to find the influence of service quality which including: tangible, reliability, responsiveness, assurance, and empathy at karaoke Inul Vizta Tanjung on customer satisfaction. This research uses descriptive analysis, simple Linear Regression analysis, validity and reliability test and t test. Populations in this study are 138 persons. The sample in this resech area 100 persons o f karaoke Inul Vizta Tanjung customers with a accidental sampling method and slovin formula to analyze the simple data. Data collected using a questionnaire technique with likert's scale, interview and documentation.The data analysis technique and research are using a validity and reliability test, classical assumption test, $t$ test and linear regression. The result of this research shows positive and significant influence on service quality to customer satisfaction at karaoke Inul Vizta Tanjung.

Keywords: tangible, reliability, responsiveness, assurance, empathy, customer satisfaction

Abstrak: Tujuan dari penelitian ini adalah untuk menemukan pengaruh kualitas pelayanan yang terdiri dari bukti fisik, kehandalan, kesigapan, jaminan dan impati yang diberikan oleh Karaoke Inul Vizta Tanjung terhadap kepuasaan pelanggan. Populasi dari penelitian ini adalah tamu-tamu dari Karaoke Inul Vizta Tanjung sejumlah sekitar 138 orang. Sampel pada penelitian ini adalah 100 orang yang diambil dengan metode accidental sampling dan formula slovin untuk menganalisis data sederhana. Data dikumpulkan dengan melalui kuisioner, wawancara menggunakan sekala likert dan dukumentasi. Tehnik analisis data menggunakan uji validitas dan realibilitas, uji asumsi klasik, uji t dan regresi linear. Hasil dari penelitian ini adalah bahwa terdapat pengaruh positif dansignifikan dari kualitas pelayanan terhadap kepuasaan pelanggan pada Karaoke Inul Vizta Tanjung.

Kata kunci : bukti fisik, kehandalan, kesigapan, jaminan,empati, kepuasan pelanggan

\section{Latar Belakang}

Kondisi persaingan yang semakin tinggi antar perusahaan, setiap perusahaan saling berpacu untuk memperluas pasar. Harapan dari adanya perluasan pasar secara langsung adalah meningkatnya penjualan, sehingga perusahaan akan memiliki lebih banyak konsumen. Namun ada beberapa hal yang harus di pahami oleh perusahaan selaku produsen, bahwa semakin banyak konsumen maka perusahaan akan semakin sulit mengenali konsumennya secara teliti. Terutama tentang suka atau tidaknya konsumen terhadap barang atau jasa yang ditawarkan dengan alasan yang mendaasarinya.

Perusahaan yang mampu bersaing dalam pasar adalah perusahaan yang dapat menyediakan produk atau jasa yang berkualitas. Sehingga perusahaan di tuntut untuk terus melakukan perbaikan terutama pada kualitas pelayanannya. Hal ini dimaksudkan agar seluruh barang dan jasa yang ditawarkan akan mendapat tempat yang baik dimata masyarakat selaku 
konsumen dan calon konsumen. Karena konsumen dalam memilih barang dan jasa didasari motivasi yang nantinya mempengaruhi jenis, cita rasa barang dan jasa yang dibelinya.

Adanya kualitas pelayanan yang baik di dalam suatu perusahaan akan menciptakan kepuasan bagi para konsumennya. Kualitas adalah kecocokan pengguna produk (fitness for us) untuk memenuhi kebutuhan dan kepuasan pelanggan (Nasution, 2015:2). Apabila telah tercapai kepuasan pelanggan, maka akan timbul pembelian ulang dan kesetiaan dan konsumen merasa benar-benar puas, sehingga mereka akan membeli ulang serta memberi rekomendasi kepada orang lain untuk membeli di tempat yang sama. Menurut Hawkins dan Lonney di kutip dalam Tjiptono (2004:101) Indikator kepuasan pelanggan terdiri dari Kesesuaian Harapan, Minat berkunjung kembali, Kesediaan merekomendasikan.

Bagi setiap perusahaan jasa perlu berupaya memberikan yang terbaik kepada konsumennya. Untuk itu dibutuhkan identifikasi determinan utama kualitas jasa dari sudut pandang konsumen. Oleh karena itu perlu dilakukan riset untuk mengindentifikasi determinan jasa yang paling penting bagi pasar sasaran dan memperkisarkan penilaian yang diberikan pasar sasaran terhadap perusahaan pesaing berdasarkan determinan-determinan tersebut. Dengan menganalisa tanggapan konsumen terhadap variabel-variabel tersebut maka perusahaan jasa dapat menilai variabel mana yang belum sesuai dengan harapan konsumen. Sehingga dengan demikian dapat di ketahui posisi relatif perusahaan di mata konsumen. Selanjutnya perusahaan dapat memfokuskan upaya peningkatan kualitasnya tersebut sepanjang waktu karena sangat mungkin terjadi prioritas pasar mengalami perubahan.

Pada dasarnya kualitas pelayanan merupakan suatu bentuk penilian konsumen terhadap tingkat pelayanan yang diterima (perceived services) dengan tingkat pelayanan yang di harapkan (expacted services). Bagi perusahaan kuncinya adalah meyesuaikan atau melebihi harapan mutu jasa yang diinginkan konsumen. Setelah konsumen merasa puas dengan produk atau jasa yang diterimanya, konsumen akan membandingkan pelayanan yang diberikan.

Band, dalam Nasution (2015:41) perbandingan antara kualitas dari barang atau jasa yang dirasakan dengan keinginan, kebutuhan, dan harapan pelanggan. Kepuasaan konsumen akan terpenuhi apabila proses penyampaian jasa dari si pemberi jasa kepada konsumen sesuai dengan apa yang dipersepsikan konsumen. Berbagai faktor seperti : subyektivitas si pemberi jasa, keadaan psikologis (konsumen maupun pemberi jasa), kondisi lingkungan eksternal dan sebagainya tidak jarang turut mempengaruhi sehingga jasa sering di sampaikan dengan cara yang berbeda dengan yang dipersepsikan oleh konsumen.

Jumlah pelanggan sangat besar pengaruhnya terhadap kelangsungan hidup perusahaan yang bergerak dalam bidang penjualan jasa, karena bagi perusaaan jasa, pelanggan merupakan sumber pemasukan. Semakin banyak pelanggan perusahaan, maka semakin besar pemasukan yang dapat diraih perusahaan, sebaliknya semakin sedikit pelanggan perusahaan, maka semakin sedikit pula pemasukan yang dapat diraih perusahaan. Konsumen akan membandingkan layanan yang diberikan perusahaan dengan layanan yang mereka harapkan. Jika konsumen merasa puas, maka konsumen akan kembali menggunakan jasa perusahaan dan menjadi pelanggannya yang setia serta akan menceritakan pengalamannya tersebut kepada orang lain, sehingga perusahaan akan mendapatkan keuntungan dari kondisi itu, yaitu mendapatkan pelanggan yang loyal.

Bersamaan dengan adanya perubahan lingkungan yang terjadi dan adanya perubahan perilaku manusia, maka semakin mendorong bertambahnya permintaan akan kebutuhan pemakaian jasa. Perilaku konsumen didefinisikan sebagai suatu tindakan yang langsung dalam mendapatkan, mengkonsumsi serta menghabiskan produk atau jasa, termasuk proses keputusan yang mendahului dan penyusuli tindakan tersebut (Husein Umar, 2005:50).

Karaoke Inul Vizta Tanjung adalah tempat hiburan yang bersih, sopan, berkelas, Sangat tepat untuk mengajak partner bisnis, kolega dan mitra kerja dalam suasana hiburan bernyanyi karaoke yang dilengkapi komputer pencari lagu berteknologi tinggi, audio sound 
system di dalam suasana ruangan yang nyaman dengan puluhan ribu lagu-lagu kesayangan dari lagu dangdut, lagu nostalgia, hingga hit masa kini baik lokal maupun luar negeri.

Pada garis besarnya, perusahaan harus berusaha untuk mengetahui apa yang menjadi kebutuhan dan keinginan konsumen termasuk memahami perilaku konsumen dan hal-hal yang dapat memberikan kepuasaan pada konsumen (pelanggan). Karaoke Inul Vizta Tanjung diciptakan diharapkan agar bisa menjadi pilihan utama masyarakat pencinta karaoke di Indonesia. Segmentasi pasar di mulai dari kalangan usia remaja hingga orang tua. Seluruh anggota keluarga dan pebisnis bisa datang untuk menikmatinya. Menyadari hal tersebut diatas tampak betapa pentingnya pemahaman akan faktor-faktor yang mempengaruhi kepuasan pelanggan untuk mencapai keberhasilan pemasaran.

Di lingkungan Karaoke Inul Vizta Tanjung kualitas pelayanan sangat berpengaruh terhadap kepuasan pelanggan dari Karaoke Inul Vizta Tanjung itu sendiri dengan fungsi dan tujuannya yang sama yaitu untuk meningkatkan penjualan dengan respon yang baik dan berkualitas sehingga menghasilkan hasil yang memuaskan. Karaoke Inul Vizta Tanjung Tabalong merupakan sebuah perusahaan jasa yang tidak hanya dikenal sebagai tempat hiburan bernyanyi tetapi juga dikenal karena pelayanan yang diberikan. Walaupun gedung Karaoke Inul Vizta Tanjung Tabalong di tunjang dengan fasilitasnya akan tetapi jika tidak ditunjang dengan pelayanan yang memuaskan atau dengan kata lain masih terdapat pelayanan yang tidak sesuai dengan apa yang diinginkan, diharapkan pelanggan maka pelanggan akan tetap merasa tidak puas. Dari uraian di atas dapat dilihat betapa pentingnya arti layanan bagi sebuah perusahaan jasa karaoke. Kunjungan dan keluhan pelanggan Karaoke Inul Vizta Tanjung dapat diihat pada tabel 1.

Tabel 1. Kunjungan dan Keluhan Pelanggan Karaoke Inul Vizta Tanjung Tahun 2017

\begin{tabular}{clcc}
\hline No & \multicolumn{1}{c}{ Bulan } & Kunjungan Pelanggan (orang) & Keluhan Pelangggan (orang) \\
\hline 1 & Januari & 162 & 18 \\
\hline 2 & Febuari & 142 & 22 \\
\hline 3 & Maret & 161 & 16 \\
\hline 4 & April & 154 & 26 \\
\hline 5 & Mei & 179 & 11 \\
\hline 6 & Juni & 89 & 34 \\
\hline 7 & Juli & 57 & 32 \\
\hline 8 & Agustus & 152 & 25 \\
\hline 9 & September & 189 & 13 \\
\hline 10 & Oktober & 199 & 12 \\
\hline 11 & November & 135 & 26 \\
\hline 12 & Desember & 181 & 229 \\
\hline & Jumlah & 1800 & 17 \\
\hline
\end{tabular}

Tabel 1 merupakan hasil dari data daftar kunjungan konsumen rutin setiap hari di Karaoke Inul Vizta Tanjung, kunjungan konsumen mengalami ketidak stabilan. Selain itu juga, tabel diatas merupakan hasil dari data daftar keluhan untuk pelanggan yang disediakan oleh perusahaan di Karaoke Inul Vizta Tanjung melalui kotak keluhan pelanggan. Dari data tersebut dapat dilihat bahwa masih sering terjadi keluhan pelanggan mengenai tentang kualitas pelayanannya, baik itu dari segi interior (fasilitas yang disediakan) salah satunya yaitu ac dan sound system yang sering bermasalah pada saat kegiatan berlangsung sehingga pelanggan merasa terganggu dan kurang puas, dari segi penampilan serta sikap karyawan, salah satunya yaitu masih sering ditemui karyawan yang kurang ramah dan kurang sopan terhadap pelanggan pada saat melakukan pelayanan serta kurang respon karyawan kepada pelanggan apabila diminta bantuan pada saat pelayanan berlangsung, sehingga terlihat dari 
data tersebut maka peneliti ingin mengetahui pengaruh kualitas pelayanan terhadap kepuasan pelanggan pada Karaoke Inul Vizta Tanjung

Karaoke Inul Vizta Tanjung salah satu tempat hiburan keluarga yang berada di Tabalong, adapun menetapkan target pendapatan minimal Rp. 300.000.000,- perbulan, namun sejak bulan April 2017 mulai terjadi penurunan jumlah pendapatan. Jumlah pendapatan setiap bulannya naik turun atau tidak stabil. Penggambaran perkembangan target dan realisasi kegiatan usaha di Karaoke Inul Vizta Tanjung lebih jelasnya dapat dilihat pada tabel 2.

Tabel 2. Target dan Realisasi Pendapatan Jasa Karaoke Inul Vizta Tanjung Tahun 2017

\begin{tabular}{lllc}
\hline Bulan & Target $(\mathrm{Rp})$ & Realisasi $(\mathrm{Rp})$ & Persentase $(\%)$ \\
\hline Januari & $300.000 .000,-$ & $303.000 .000,-$ & 101 \\
\hline Pebruari & $300.000 .000,-$ & $284.000 .000,-$ & 94,67 \\
\hline Maret & $300.000 .000,-$ & $280.000 .000,-$ & 93,33 \\
\hline April & $300.000 .000,-$ & $245.000 .000,-$ & 81,67 \\
\hline Mei & $300.000 .000,-$ & $260.000 .000,-$ & 86,67 \\
\hline Juni & $300.000 .000,-$ & $240.000 .000,-$ & 80,00 \\
\hline Juli & $300.000 .000,-$ & $283.000 .000,-$ & 94,33 \\
\hline Agustus & $300.000 .000,-$ & $262.000 .000,-$ & 87,33 \\
\hline September & $300.000 .000,-$ & $236.000 .000,-$ & 78,67 \\
\hline Oktober & $300.000 .000,-$ & $250.000 .000,-$ & 83,33 \\
\hline November & $300.000 .000,-$ & $246.000 .000,-$ & 82,66 \\
\hline Desember & $300.000 .000,-$ & $272.000 .000,-$ & 90,66
\end{tabular}

Berdasarkan tabel 2 dapat dilihat bahwa realisasi pencapaian pendapatan Karaoke Inul Vizta Tanjung, ada pencapaian yang memenuhi target dan ada pencapaian yang tidak memenuhi target. Realisasi yang dihasilkan tidak semua mampu mencapai atau memenuhi target yang diharapkan sehingga perlu adanya perhatian khusus lagi untuk meningkatkan abseling terhadap konsumen agar dapat meningkatkan hasil pencapaian pendapatan penjualan.

Berdasarkan uraian diatas, dapat ditarik kesimpulan bahwa kepuasan pelanggan sangat penting untuk merebut minat pelanggan agar senantiasa menggunakan jasa yang ditawarkan dan memberikan rekomendasi pada orang lain, sehingga perusahaan perlu meningkatkan kualitas pelayanan terhadap pelanggan, maka rumusan masalah dalam penelitian ini adalah : "Apakah kualitas pelayanan berpengaruh terhadap kepuasan pelanggan dalam menggunakan hiburan jasa Karaoke Inul Vizta Tanjung?”.

\section{Kajian Literatur}

Menurut Kotler dan Keller (2009:6), pengertian dari manajemen pemasaran adalah seni dan ilmu memilih pasar sasaran dan mendapatkan, menjaga dan menumbuhkan pelanggan dengan menciptakan, menyerahkan, dan mengkomunikasikan nilai pelanggan yang unggul.Menurut Wahjono (2010:130), pengertian manajemen pemasaran adalah suatu proses perencanaan dan pelaksanaan dari bentuk penjualan, pemberian harga, promosi dan distribusi dari barang-barang, jasa dan gagasan untuk menciptakan pertukaran dengan kelompok sasaran yang memenuhi tujuan pelanggan dan organisasi. Menurut Ginting (2011;280 manajemen pemasaran menyangkut pengelolaan permintaan (managing Demand) yang pada gilirannya pengelolaan hubungan konsumen ada dua hal yang perlu diperhatikan yaitu pengelolaan permintaan (managing demand) dan hubungan pelanggan yang menguntungkan. Dari definisi para ahli tersebut dapat disimpulkan bahwa pengertian manajemen pemasaran adalah proses penetapan tujuan-tujuan pemasaran bagi suatu organisasi (dengan mempertimbangakan 
sumber daya internal dan peluang pasar), perencanaan, pelaksanaan aktivitas untuk memenuhi tujuan-tujuan tersebut dan mengukur kemajuan kearah pencapaiannya.

Pemasaran yang diadopsi berasal dari amarican marketing association menurut Kotler dan Keller (2012) yang mendefinisikannya sebagai berikut: Pemasaran adalah suatu fungsi organisasi dan sekumpulan proses untuk menciptakan, mengkomunikasikan dan menyampaikan nilai kepada pelanggan serta mengelola hubungan dengan pelanggan yang kesemuanya dapat memberikan manfaat bagi organisasi dan para stakeholder nya. Menurut Christoper lovelock dan Lauren $\mathrm{K}$ Wright pemasaran jasa adalah bagian dari sistem jasa keseluruhan dimana perusahaan tersebut memiliki sebuah bentuk kontak dengan pelanggannya, mulai dari penagihan, hal itu mencakup kontak yang dilakukan pada saat penyerahaan jasa.

Marketing mix untuk pemasaran jasa tidak jauh berbeda dengan marketing mix untuk pemasaran produk, hanya saja ada beberapa elemen yang perlu ditambahkan sehingga dapat menunjang pemasaran jasa tersebut. Menurut Kotler dan Keller (2007:23), bauran pemasaran merupakan seperangkat alat pemasaran yang digunakan perusahaan untuk mengejar tujuan pemasaran. Dengan demikian, dapat diartikan bahwa bauran pemasaran adalah sekumpulan variabel yang terkendali dimana satu sama lain saling berkaitan dan dikombinasikan oleh perusahaan dengan tepat agar menjadi suatu bauran yang dapat digunakan untuk mencapai tujuan pemasaran perusahaan.

Lupiyoadi dan Hamdani (2006:70), mengemukakan tentang elemen yang terdapat dalam bauran pemasaran jasa yaitu:

1. Produk (Product)

Merupakan keseluruhan konsep objek atau proses yang memberikan sejumlah nilai kepada konsumen, yang perlu diperhatikan dalam produk adalah konsumen tidak hanya membeli fisik dari produk saja tetapi membeli manfaat dan nilai dari produk tersebut yang disebut "the offer".

2. Harga (Prince)

Berkaitan dengan strategi penentuan harga (pricing) yang sangat signifikan dalam pemberian nilai kepada konsumen, dan mempengaruhi citra produk, serta keputusan konsumen untuk membeli.

3. Tempat (Place)

Tempat dalam jasa merupakan gabungan antara lokasi dan keputusan atas saluran distribusi, dalam hal ini berhubungan dengan bagaimana cara penyampaian jasa kepada konsumen dan dimana lokasi yang strategis.

4. Promosi (Promotion)

Promosi adalah cara mengkomunikasikan produk jasa kepada konsumen sehingga konsumen merasa tertarik dan pada akhirnya akan melakukan pembelian. Promosi tersebut dapat dilakukan dengan melalui iklan baik iklan media cetak maupun elektronik, personal selling, public relation dan pemasaran secara langsung.

5. Orang (People)

Orang adalah sumber daya manusia yang berfungsi sebagai penyedia jasa. Orang harus memiliki kualitas yang terbaik untuk dapat memberikan konsumen kepuasan dalam memenuhi kebutuhannya.

6. Proses (Process)

Proses merupakan gabungan semua aktivitas umumnya terdiri dari prosedur, jadwal pekerjaan, mekanisme, aktivitas, dan hal-hal rutin, dimana jasa dihasilkan dan disampaikan kepada konsumen.

7. Layanan Konsumen (Costumer Service)

Layanan konsumen meliputi aktivitas untuk memberikan kegunaan waktu dan tempat termasuk pelayanan pratransaksi, saat transaksi dan pasca transaksi. 
Kualitas adalah kecocokan pengguna produk (fitness for us) untuk memenuhi kebutuhan dan kepuasan pelanggan (Nasution, 2015:2). Pelayanan (jasa) adalah merupakan aktivitas atau manfaat yang ditawarkan oleh satu pihak kepada pihak lain yang dasarnya tidak berwujud dan tidak menghasilkan kepemilikan apapun (Nasution, 2015:64).

Zeithanml, mengemukakan lima dimensi dalam menentukan kualitas jasa yaitu keandalan, keresponsipan (ketanggapan), keyakinan, empati, serta berwujud (Philip kotler, 1994:561, dalamNasution, 2015:58). Menyadari hal tersebut tampak betapa pentingnya pemahaman akan faktor-faktor yang mempengaruhi kepuasan pelanggan untuk mencapai keberhasilan pemasaran. Dalam menghadapi hal tersebut ada beberapa indikator yang dapat mempengaruhi kepuasan pelanggan untuk mempergunakan jasa hiburan pada Karaoke Inul Vizta Tanjung antara lain:

1. Tangible, meliputi penampilan gedung, interior bangunan, dan penampilan karyawan Karaoke Inul Vizta Tanjung .

2. Reliability, meliputi kemampuan karyawan Karaoke Inul Vizta Tanjung untuk memberikan pelayanan yang terbaik.

3. Responsiveness, meliputi kesediaan karyawan Karaoke Inul Vizta Tanjung untuk membantu konsumen dan memberikan pelayanan yang cepat pada saat diminta bantuan.

4. Assurance, meliputi sopan santun para karyawan Karaoke Inul Vizta dan kemampuan mereka untuk membangkitakan rasa kepercayaan pelanggan

5. Empati, rasa perhatian secara pribadi yang diberikan perusahaan Inul Vizta karaoke pada konsumen.

Pengertian Kepuasan Pelanggan, Band (1971:79, dalam Nasution, 2015:41) menyatakan secara sederhana definisi kepuasan pelanggan adalah sebagai perbandingan antara kualitas dari barang atau jasa yang dirasakan dengan keinginan, kebutuhan, dan harapan pelanggan. Apabila telah tercapai kepuasan pelanggan, maka akan timbul pembelian ulang dan kesetiaan. Apabila kepuasan pelanggan boleh dinyatakan sebagai suatu Rasio atau perbandingan (Nasution, 2025:41), maka dapat dirumuskan kepuasan pelanggan sebagai berikut:

$$
\mathrm{Z}=\mathrm{X} / \mathrm{Y}
$$

Dimana :

$\mathrm{Z}$ : kepuasan pelanggan

$\mathrm{X}$ : Kualitas yang dirasakan oleh pelanggan

$\mathrm{Y}$ : kebutuhan, keinginan, dan harapan pelanggan.

Jika pelanggan merasakan bahwa kualitas dari produk/jasa melebihi kebutuhan, keinginan, dan harapan mereka, maka kepuasan pelanggan akan menjadi tinggi atau paling sedikit bernilai besar dari satu $(Z>1)$. Sedangkan pada sisi lain, apabila pelanggan merasakan bahwa kualitas dari produk atau jasa lebih rendah atau lebih kecil dari kebutuhan, keinginan, dan harapan, maka pelanggan akan menjadi lebih rendah atau bernilai lebih kecil dari satu ( $\mathrm{Z}$ $<1)$.

Menurut Hawkins dan Lonney di kutip dalam Tjiptono (2004:101) Indikator kepuasan pelanggan terdiri dari :

1. Kesesuaian Harapan

Merupakan tingkat kesesuaian antara kinerja produk yang diharapkan oleh pelanggan dengan yang dirasakan oleh pelanggan, meliputi :

a. Produk yang di peroleh sesuai atau melebihi dengan yang diharapkan

b. Pelayanan oleh karyawan yang di peroleh sesuai atau melebihi dengan yang diharapkan 
c. Fasilitas penunjang yang di peroleh sesuai atau melebihi dengan yang diharapkan

2. Minat berkunjung kembali

Merupakan kesediaan pelanggan untuk berkunjung kembali atau melakukan pembelian ulang terhadap produk terkait, meliputi :

a. Berminat untuk berkunjung kembali karena pelayanan yang diberikan oleh karyawan memuaskan

b. Berminat untuk berkunjung kembali karena nilai dan manfaat yang di peroleh setelah mengkonsumsi produk

c. Berminat untuk berkunjung kembali karena fasilitas penunjang yang disediakan memadai

3. Kesediaan merekomendasikan

Merupakan kesediaan pelanggan untuk merekomendasikan produk yang telah dirasakannya kepada teman atau keluarga meliputi :

a. Menyarankan teman atau kerabat untuk membeli produk yang ditawarkan karena pelayanan yang memuaskan

b. Menyarankan teman atau kerabat untuk membeli produk yang ditawarkan karena fasilitas penunjang yang disediakan memadai

c. Menyarankan teman atau kerabat untuk membeli produk yang ditawarkan karena nilai atau manfaat yang didapat setelah mengkonsumsi sebuah produk jasa

Faktor-faktor yang mempengaruhi kepuasaan pelanggan adalah mutu produk dan pelayanannya, kegiataan penjualaan, pelayanan setelah penjualan dan nilai-nilai perusahaan. Kepuasaan dibagi atas dua macam, yaitu kepuasaan fungsional merupakan kepuasaan yang di peroleh dari fungsi suatu produk yang dimanfaatkan sedangkan kepuasaan psikologika merupakan kepuasaan yang di peroleh dari atribut yang bersifat tidak berwujud dari produk. Selanjutnya, pelangganpun dapat dibagi atas dua macam, yaitu pelanggan eksternal adalah pelanggan yang ada di luar organisasi sedangkan pelanggan internal merupakan orang orang yang melakukan proses selanjutnya dari pekerjaan orang sebelumnya (Husein Umar 2005:51)

Kepuasaan pelanggan sangat tergantung pada presepsi dan ekpektasi, maka terdapat beberapa faktor-faktor yang mempengaruhi prespsi dan harapan pelanggan (Gasperz,1997:35, dalam Nasution, 2015:42) adalah sebagai berikut:

1. Kebutuhan dan keinginan yang berkaitan dengan hal-hal yang dirasakan pelanggan ketika sedang mencoba melakukan transaksi dengan produsen atau pemasok produk (perusahaan).

2. Pengalaman masa lalu ketika mengkonsumsi produk dari perusahaan maupun pesaingpesaingnya

3. Pengalaman dari teman teman, dimana mereka akan menceritakan kualitas produk yang akan dibeli oleh pelanggan tersebut

4. Komunikasi melalui iklan dan pemasaran juga dapat mempengaruhi prepsesi pelanggan

\section{Metode Penelitian}

Populasi adalah wilayah generalisasi yang terdiri atas obyek atau subyek yang mempunyai kualitas dan karakteristik tertentu yang ditetapkan oleh peneliti untuk dipelajari dan kemudian ditarik kesimpulannya (Sugiyono, 2006:73). Populasi dalam penelitian ini adalah seluruh konsumen yang telah melakukan pemakai jasa pada karaoke Inul Vizta Tanjung. Berdasarkan informasi yang didapat, konsumen yang melakukan kunjungan selama satu tahun terahkir pada tahun 2017 yaitu sebanyak 43.000 orang, maka apabila di asumsikan setiap orang sebanyak tiga kali berkunjung maka terdapat 1.650 orang selama satu 
tahun, maka jumlah populasi sebanyak 138 dalam satu bulan orang yang berkunjung pada karaoke Inul Vizta Tanjung.

Sampel adalah bagian dari sejumlah karakteristik yang dimiliki oleh populasi yang digunakan untuk penelitian. Untuk itu sampel yang diambil dari populasi harus betul-betul mewakili dan harus valid, yaitu harus bisa mengukur sesuatu yang seharusnya diukur (V. Wiratna Sujarweni, 2014:65).

Pengukuran sampel yang digunakan menurut V.Wiratna Sujarweni (2014:66) menggunakan rumus slovin yaitu:

$\mathrm{n}=\frac{\mathrm{N}}{1+\left(\mathrm{Nx} \mathrm{e}^{2}\right)}$

Dimana : $\mathrm{n}=$ Ukuran Sampel

$$
\begin{aligned}
& \mathrm{N}=\text { Populasi } \\
& \mathrm{e}=\text { Error Sampel }
\end{aligned}
$$

Berdasarkan rumus di atas, maka sampel pada penelitian ini dengan tingkat error 5\% $(0,05)$ adalah:

$$
\begin{aligned}
& \mathrm{n}=\frac{\mathrm{N}}{1+\left(\mathrm{N} \mathrm{x} \mathrm{e}^{2}\right)} \\
& \mathrm{n}=\frac{150}{1+\left(150 \times 0,05^{2}\right)} \\
& \mathrm{n}=\frac{150}{1,375} \\
& \mathrm{n}=110 \text { responden }
\end{aligned}
$$

Berdasarkan hasil perhitungan dengan rumus di atas, maka didapatkan sampel pada penelitian ini adalah sebanyak 110 responden pelanggan.

Menurut Suharyadi dan Purwnto (2009:171), untuk menentukan ada tidaknya pengaruh variable independen $(\mathrm{X})$ terhadap variabel dependen dapat digunakan model analisis regresi linear sederhana dengan model persamaan :

$$
\mathbf{Y}=\mathbf{a}+\mathbf{b X}
$$

Dimana : $Y=$ Kepuasan pelanggan

$\mathrm{X}=$ kualitas pelayanan

$\mathrm{a}=$ konstanta

$\mathrm{b}=$ koefisien regresi

Pembuktian terhadap hipotesis yang diujikan dapat dilakukan dengan menggunakan serangkaian teknik analisis berikut:

1. Uji t dilakukan untuk mengetahui ada tidaknya pengaruh variabel bebas dengan variabel terikat secara sendiri-sendiri (parsial).

2. Koefisien determinasi adalah suatu nilai yang menggambarkan seberapa besar perubahan variasi dari variabel dependen bisa dijelaskan oleh perubahan atau variasi dari variabel 
independen, dengan mengetahui nilai koefisien determinasi maka bisa dijelaskan kebaikan dari model regresi dalam memprediksi variabel dependen.semakin tinggi nilai koefisien determinasi akan semakin baik kemampuan variabel independen dalam menjelaskan perilaku variabel dependen. Besarnya koefisien determinasi adalah kuadrat dari koefisien korelasi dan rumusan sebagai berikut:

$$
\mathbf{r}^{2}=\frac{n \sum X Y-\left(\sum X\right)\left(\sum Y\right)}{\left.\sqrt{\left[n\left(\sum_{X} 2\right)\right.}-\left(\sum X\right)^{2}\right]\left[n\left(\sum_{Y} 2\right)-\left(\sum Y\right)^{2}\right]}(\text { Sugiyono, 2011:106) }
$$

Dimana : $r^{2}=$ nilai koefisien determinasi

$$
\begin{aligned}
& \mathrm{n}=\text { jumlah sampel } \\
& \mathrm{X}=\text { nilai variabel bebas } \\
& \mathrm{Y}=\text { nilai variabel terikat. }
\end{aligned}
$$

\section{Hasil Penelitian dan Pembahasan}

Dari hasil pengujian estimasi regresi yang telah dikemukakan sebelumnya yaitu dengan melihat tabel Cofficients pada Unstandarized Coffficients hasil estimasi regresi dengan SPSS versi 18.00, maka didapat persamaan regresi sederhana sebagai berikut:

$\mathrm{Y}=\mathrm{a}+\mathrm{bX}$

$\mathrm{Y}=0.115+0.585 \mathrm{X}$

Tabel 3. Hasil Estimasi Regresi

\begin{tabular}{|l|l|c|c|c|}
\hline \multicolumn{1}{|c|}{$\begin{array}{c}\text { Variable } \\
\text { Dependen }\end{array}$} & \multicolumn{1}{|c|}{$\begin{array}{c}\text { Variable } \\
\text { Independent }\end{array}$} & $\begin{array}{c}\text { Koefisien } \\
\text { Regresi }\end{array}$ & $\mathrm{t}_{\text {hitung }}$ & Sig. \\
\hline $\begin{array}{l}\text { Kepuasan } \\
\text { Pelanggan }(\mathrm{Y})\end{array}$ & $\begin{array}{l}\text { Kualitas } \\
\text { Pelayanan }(\mathrm{X})\end{array}$ & 0,585 & 17,271 & 0,000 \\
\hline Konstanta $: 0,115$ \\
\hline \multicolumn{2}{|l|}{ Koefisien Determinasi $: 0.753$} \\
\hline
\end{tabular}

Nilai konstanta sebesar 0.115 artinya apabila tidak ditambah variabel kualitas pelayan, maka kepuasan pelanggan tetap sebesar 0.115. Nilai koefisien regresi (b) sebesar 0.585 artinya apabila ditambah variabel kualitas pelayan, maka kepuasan pelanggan akan naik sebesar 0.585 .

Berdasarkan estimasi regresi seperti yang dikemukakan sebelumnya diketahui bahwa nilai $t_{\text {tabel }}$ untuk menguji $t_{\text {hitung }}$ pada tingkat kepercayaan $95 \%$ dan taraf signifikan $5 \%$ dan derajat kebebasan $(\mathrm{df})=(\mathrm{n}-\mathrm{k})$, maka $(\mathrm{df})=(\mathrm{n}-\mathrm{k})$, jadi $100-2=98$, maka $\mathrm{t}_{\text {tabel }}=1,984$

Hasil uji $\mathrm{t}$ (tabel Coefficient) diperoleh nilai $\mathrm{t}_{\text {hitung }}$ sebesar 17.271 sedangkan $t_{\text {tabel }}$ 1,98447 yang berarti $t_{\text {hitung }}$ lebih besar dari pada $t_{\text {tabel}}$, sehingga dapat diartikan bahwa ada pengaruh positif dan signifikan yang diberikan variabel kualitas pelayan terhadap kepuasan pelanggan di Karaoke Vitza Inul Tanjung.

Hasil uji t ini sejalan dengan angka sig 0,000 yang lebih kecil dari pada alpha 0,05 sehingga disimpulkan bahwa kualitas pelayan (X) memiliki pengaruh signifikan terhadap kepuasaan pelanggan (Y) pada karaoke Vitza Inul Tanjung. Dengan kata lain, Ho yang 
menyatakan variabel kualitas pelayan tidak berpengaruh signifikan terhadap kepuasaan pelanggan pada Karaoke Inul Vizta Tanjung ditolak.

Koefisien determinasi adalah suatu nilai yang menggambarkan seberapa besar kontribusi atau varian dari suatu variabel dependen bisa dijelaskan oleh perubahan atau varian dari variabel independen.

Berdasarkan estimasi regresi yang dikemukakan sebelumnya, hasil koefisien determinasi menunjukkan angka 0.753 atau sebesar $75.3 \%$ dari hasil $\left(\mathrm{r}^{2} \times 100 \%\right)$ yang berarti dapat di tafsirkan bahwa variabel bebas (kualitas pelayanan) memiliki kostribusi sebesar $75,3 \%$ terhadap kepuasan pelanggan dan sisanya $24,7 \%$ dikontribusi oleh variabel lain selain kualitas pelayanan.

Temuan-temuan yang telah didapat pada hasil penelitian ini dapat dijelaskan sebagai berikut :

1. Pada uji validitas dan reliabilitas, pada variabel kualitas pelayan ( $X$ ) dan variabel kepuasan pelanggan ( Y ) semua butir pernyataan dinyatakan valid dan reliabel, artinya butir pernyataan kuesioner dianggap mampu mengungkapkan sesuatu yang akan diukur dan jawaban responden terhadap pernyataan konsisten atau stabil dari waktu ke waktu, sehingga butir pernyataan indikator tersebut digunakan untuk estimasi regresi.

2. Pada uji asumsi klasik, tidak terjadi heteroskedastisitas, karena tidak ada pola yang jelas serta titik-titik menyebar di atas dan di bawah angka 0 pada sumbu $\mathrm{Y}$, sehingga dapat dikatakan uji heteroskedastisitas terpenuhi. Begitu pula dengan uji normalitas, dimana grafik histogram memberikan pola distribusi yang tidak menceng (skewness) ke kiri maupun ke kanan, melainkan normal berada di tengah, hal ini menunjukkan bahwa uji normalitas berdasarkan grafik histogram terpenuhi atau dengan kata lain model regresi tidak menyalahi asumsi normalitas dan berdasarkan gambar Normal P-Plot data menyebar di sekitas garis lurus diagonal dan mengikuti model regresi sehingga dapat disimpulkan bahwa data yang diolah merupakan data yang berdistribusi normal sehingga uji normalitas terpenuhi.

3. Pada uji estimasi regresi, dimana:

a. Persamaan regresi yang didapat adalah $Y=-0,115+0,585 X$. Nilai konstanta sebesar 0,115 dan koefisien regresi 0,585 berarti apabila ditambah (ditingkatkan) satu satuan variabel kualitas pelayan (X), maka kepuasaan pelanggan (Y) akan bertambah (meningkat) sebesar 0,585kali. Apabila kualitas pelayanan tidak ditambah (ditingkatkan), maka kepuasan pelanggan akan tetap sebesar-0,115 hal ini menunjukkan pentingnya kualitas pelayanan pada Karaoke Inul Vizta Tanjung , jika kualitas pelayan ditingkatkan, maka kepuasan pelanggan akan meningkat.

b. Hasil uji t (tabel coefficients) diperoleh nilai $t_{\text {hitung }}$ sebesar 17.271 sedangkan $t_{\text {tabel }} 1,984$ yang berarti $t_{\text {hitung }}$ lebih besar dari pada $t_{\text {tabel }}$, sehingga dapat diartikan bahwa ada pengaruh positif dan signifikan yang diberikan variabel kualitas pelayanan terhadap kepuasan pelanggan pada Karaoke Inul Vizta Tanjung. Hasil uji t ini sejalan dengan angka sig 0,000 yang lebih kecil dari pada alpha 0,005 sehingga disimpulkan bahwa kualitas pelayan (X) memiliki pengaruh signifikan terhadap kepuasan pelanggan (Y) pada Karaoke Inul Vizta Tanjung. Dengan kata lain, Ho yang menyatakan variabel kualitas pelayan tidak berpengaruh signifikan terhadap kepuasan pelanggan pada karaoke Inul Vizta Tanjung ditolak dan $\mathrm{Ha}$ yang menyatakan variabel kualitas berpengaruh signifikan terhadap kepuasan pelanggan pada Karaoke Inul Vizta Tanjung.

c. Hasil koefisien determinasi menunjukkan angka 0.753 atau sebesar 75,3\% dari hasil $\left(\mathrm{r}^{2}\right.$ $\mathrm{x} 100 \%$ ) yang berarti bahwa varian perubahan memberikan kontribusi sebesar $75,3 \%$ terhadap kepuasan pelanggan dan sisanya $24,7 \%$ dikontribusi oleh variabel lain selain kualitas pelayanan. 


\section{Kesimpulan}

Berdasarkan hasil analisis peneliti pengaruh kualitas pelayanan terhadap kepuasan pelanggan pada Karaoke Inul VitzaTanjung yang telah dipaparkan pada sebelumnya, maka dapat diambil kesimpulan bahawa kualitas pelayanan memang mempengaruhi secara positif signifikan. Ditemukan pula bahwa sebagian besar faktor pembentuk kepuasan pelanggan adalah kualitas pelayanan yang baik merupakan faktor yang perlu mendapat perhatian khusus.

Berdasarkan hasil penelitian serta hal-hal yang terkait dengan keterbatasan penelitian ini, maka dapat diberikan saran-saran sebagai berikut:

1. Penelitian ini menunjukkan bahwa kualitas pelayan berpengaruh positif dan signifikan terhadap Kepuasan pelanggan. Maka dari itu, pemilik Karaoke Inul Vizta Tanjung Tabalong hendaknya lebih meningkatkan kualitas pelayanan agar yang dapat dirasakan oleh pelanggan adalah kepuasan sehingga diharapkan dapat semakin meningkatkan kepuasan pelanggan.

2. Dari hasil koefisien determinasi variabel kualitas pelayanan mengkontribusi sebanyak $75,3 \%$ terhadap kepuasan pelanggan dan sisanya 24,3\% terdapat pada variabel lain, jadi pemilik Karaoke Inul Vizta Tanjung juga harus memperhatikan variabel-variabel lainnya yang tidak diteliti dalam penelitian ini juga berpengaruh terhadap kepuasan pelanggan seperti promosi, harga dan lainnya.

\section{DAFTAR PUSTAKA}

Adam, Muhammad 2015. Manajemen Pemasara Jasa. Cetakan Kesatu. Bandung : Alfabeta.

Lupiyoadi, Rambat dan Hamdani, A 2008. Manajemen Pemasaran Jasa, Edisi 2. Jakarta : Salemba Empat.

Kotler, Philip dan Kevin Lane Keller, 2009. Manajemen Pemasaran, Edisi Ketigabelas. Jilid 2. Jakarta: Erlangga.

Priyatno, Dwi. 2010. Paham Analisis Statistik Data dengan SPSS. Yogyakarta : Media Kom. Riduan, 2009. Belajar Mudah Penelitian. Bandung : Alfabeta.

Sudaryono, 2016. Manajemen Pemasaran. Yogykarta : C.V ANDI OFFSET

Sugiyono, 2011. Metode Penelitian Kuantitatif, Kualitatif Dan $R$ \& D: Cetakan Keempatbelas. Bandung : Alfabeta.

Sujarweni, V. Wiratna, 2014. Metodologi Penelitian. Yogyakarta : PT Pustaka Baru. Tiurma, Elsa. 2016. Pengertian Indikator Kepuasan Pelanggan Menurut Para Ahli. http://etalasepustaka.blogspot.co.id/2016/08/pengertian-indikator-kepuasan-pelangganmenurut-para-ahli.html. Diakses pada tanggal 26 April 2017. 